\title{
$4-2015$
}

\section{Interferon lambda-3 polymorphism and response to pegylated interferon in patients with hepatitis $D$}

\author{
Zaigham Abbas \\ Aga Khan University, zaigham.abbas@aku.edu \\ javed Yakoob \\ Aga Khan University, javed.yakoob@aku.edu \\ Muhammad A. Umer, \\ Aga Khan University \\ Minaam Abbas \\ Aga Khan University \\ Saeed Hamid \\ Aga Khan University, saeed.hamid@aku.edu
}

Follow this and additional works at: https://ecommons.aku.edu/pakistan_fhs_mc_med_gastroenterol

Part of the Digestive System Diseases Commons, and the Gastroenterology Commons

\section{Recommended Citation}

Abbas, Z., Yakoob, j., Umer,, M. A., Abbas, M., Hamid, S. (2015). Interferon lambda-3 polymorphism and response to pegylated interferon in patients with hepatitis D. Antiviral Therapy, 20(5), 529-533.

Available at: https://ecommons.aku.edu/pakistan_fhs_mc_med_gastroenterol/107 


\section{Interferon lambda-3 polymorphism and response to pegylated interferon in patients with hepatitis $D$}

Zaigham Abbas, Javed Yakoob, Muhammad A Umer, Minaam Abbas, Saeed Hamid

Antiviral Therapy 2015; 10.3851/IMP2943

Submission date 5th December 2014

Acceptance date 26th January 2015

Publication date 10th February 2015

This provisional PDF matches the article and figures as they appeared upon acceptance.

Copyedited and fully formatted PDF and full text (HTML) versions will be made available soon.

For information about publishing your article in Antiviral Therapy go to http://www.intmedpress.com/index.cfm?pid=12 


\title{
Original article
}

\section{Interferon lambda-3 polymorphism and response to pegylated interferon in patients with hepatitis D}

Zaigham Abbas ${ }^{1,2 *}$, Javed Yakoob², Muhammad A Umer ${ }^{1}$, Minaam Abbas ${ }^{1}$, Saeed Hamid ${ }^{2}$

${ }^{1}$ Department of Medicine, Orthopedic and Medical Institute, Karachi, Pakistan

${ }^{2}$ Department of Medicine, The Aga Khan University Hospital, Karachi, Pakistan

*Corresponding author e-mail: drzabbas@gmail.com

\begin{abstract}
Background: Specific single nucleotide polymorphisms (SNPs) near the interferon lambda 3 (IFN $\lambda 3$ ) gene (formal interleukin 28B), influence the response to treatment with interferon in hepatitis $C$ patients. We aimed to investigate such an influence in hepatitis $D$ patients.

Methods: Study population consisted of hepatitis $D$ patients who were previously treated with pegylated interferon for one year and spontaneous clearers of the virus post recent superinfection. SNP of IFN $\lambda 3$, rs12979860 was determined by PCR-RFLP protocol.
\end{abstract}

Results: The total number of patients were 64; median age 30.5 years, male 53 . Patients with sustained virologic response one year post-treatment were 17, nonresponders 29, relapsers 11, and spontaneous clearers post superinfection 07. Cirrhosis was present in 28 (44\%). IFN $\lambda 3$, rs 12979860 genotype CC was present in $41(64.1 \%)$, CT $21(32.8 \%)$, and TT $02(3.1 \%)$. There was no difference in the body mass index, baseline ALT, HBeAg and HBV DNA status among patients with sustained response and response failure (no response or relapse). The median age of response failures was 33.5 years compared to 26 in responders $(p=0.024)$. They had higher GGT levels $(p=0.030$ ) and cirrhosis (0.003). Genotype CC was present in 29/40 of response failures compared to $9 / 17$ of the responders $(p=0.152)$. Logistic regression analysis showed that cirrhosis was the independent risk factor for failure to have a response $(p=0.001) .4 / 7$ patients with spontaneous clearance had genotype CC.

Conclusions: IFN $\lambda 3$ rs12979860 SNP does not have any significant influence on the long term hepatitis D clearance. Presence of cirrhosis may influence the response.

Accepted 26 January 2015, published online 10 February 2015

Running title: IFN $\lambda 3$ polymorphism and hepatitis $D$ 


\section{Introduction}

Genome-wide association studies (GWAS) studies have shown that a single nucleotide polymorphism (SNP) rs12979860 near the interferon lambda-3 (IFN $\lambda 3$ ) gene, (formally known as interleukin 28B), on chromosome 19 , is associated with variable responses to the interferon therapy in hepatitis $\mathrm{C}$. The CC genotype of IFN $\lambda 3$ rs12979860 is associated with two to three fold increases in sustained virologic response as compared with either CT or TT genotype [1,2]. In case of hepatitis $B$, the association of IFN$\lambda 3$ polymorphism with response to interferon has not been confirmed [3]. A recent study has shown that IL28-B polymorphisms are related to differing response to pegylated interferon (Peg-IFN) in the treatment of $\mathrm{HBeAg}$-negative chronic hepatitis $\mathrm{B}$, which may also be hepatitis B virus genotype dependent [4].

Although the prevalence of hepatitis $D$ has decreased in Europe, it is still prevalent in many countries of Asia Pacific region including Pakistan [5-7]. Hepatitis D is a difficult-to-treat infection. Interferon, standard or pegylated, is the only treatment option available to hepatitis D patients. Peg-IFN for hepatitis $D$ is of limited efficacy $[8,9]$ and the addition of a nucleoside analog does not improve the response [10]. The agent seems effective in suppressing viral and liver disease activity in some patients, but this improvement is not sustained in the majority of patients.

Not enough data is available on the association between IFN $\lambda 3$ polymorphisms and hepatitis $D$ virus (HDV) response to Peg-IFN based therapy and spontaneous clearance rate. This study aimed to find out IFN $\lambda 3$ rs12979860 genotypes in responders, non-responders and relapsers to the Peg-IFN therapy and in spontaneous clearers of hepatitis $D$ infection.

\section{Methods}

\section{Patients}

Study population consisted of HBsAg and anti-HDV antibody positive patients with compensated liver disease who visited our clinic in a period of two years for whom longitudinal observations were available from the medical records. Patients were considered to have chronic hepatitis D when HDV-RNA was detectable in patients reactive for anti-HDV antibodies for more than six months. Subjects were considered to have achieved spontaneous viral clearance post superinfection if they had two consecutive negative HDV-RNA results six months apart without any antiviral treatment. Patients with detectable HDV RNA who had been previously treated with Peg-IFN for one year, were categorized as responders, nonresponders and relapsers to the therapy. Responders were defined as patients who had negative HDV RNA at the end of treatment and one year post treatment.

Informed consent was taken from each patient. Baseline characteristics at the time of commencement of therapy were noted from the records, including age, sex, body mass index (BMI), 
HBeAg status, HBV DNA and HDV RNA, qualitative or quantitative, and type and duration of therapy received.

Exclusion criteria were treatment with standard interferon, duration of treatment less than or more than one year, concomitant or previous nucleos (t) ide consumption, co-infection with hepatitis C or HIV, decompensated cirrhosis, alcohol abuse, autoimmune disorders or hepatocellular carcinoma. We also excluded patients where end of treatment and follow up HDV RNA status was not documented. The study was approved by the Ethics Committee of the hospital.

Blood samples were taken for HDV RNA and SNP. SNP of IFN $\lambda 3$ rs12979860 was determined by polymerase chain reaction-restriction fragment length polymorphism (PCR-RFLP) protocol as mentioned below. HDV RNA clearance was compared in lambda-3 rs12979860 "CC" with "non CC".

\section{IL28B genotyping}

$7 \mathrm{~mL}$ of blood will be drawn into EDTA (lavender top) tube. Genotyping for the IL-28B rs12979860 C/T polymorphism was performed by polymerase chain reaction based restriction fragment length polymorphism assay. Genomic DNA was extracted from whole blood samples by means of the QIAamp DNA blood mini kit (Qiagen, Milan, Italy) according to manufacturer's instruction. A 242 base pair (bp) product was obtained with the forward primer 5'-GCTTATCGCATACGGCTAGG-3' and the reverse primer 5'-AGGCTCAGGGTCAATCACAG-3', previously described [11]. PCR amplification was carried out in a total volume of $10 \mu$ l containing $10 \mathrm{mM}$ Tris- $\mathrm{HCl}(\mathrm{pH} 8.3), 50 \mathrm{mM} \mathrm{KCl}$, Tween-20 0.01\%, $0.2 \mathrm{mM}$ deoxyribonucleotides, 2-4 pmol of each primer, $2.0 \mathrm{mM} \mathrm{MgCl}$, 0.5 units hot-start Taq DNA polymerase (Promega). Samples containing $10 \mathrm{ng}$ of genomic DNA were subjected to 40 cycles of denaturation (at 95 ${ }^{\circ} \mathrm{C}$ for $30 \mathrm{~s}$ ), annealing (at $62{ }^{\circ} \mathrm{C}$ for $30 \mathrm{~s}$ ), and elongation (at $72{ }^{\circ} \mathrm{C}$ for $30 \mathrm{~s}$ ) using a Perkin Elmer 9700 thermal cycler. In a total volume of $20 \mu \mathrm{l}, 10 \mu \mathrm{l}$ of the amplified products were digested with 1 unit of the BstU-I restriction endonuclease (New England Bioloabs, UK) at $60^{\circ} \mathrm{C}$ overnight. The fragments digested were, respectively, $135+82+25 \mathrm{bp}$ for the $\mathrm{C}$ allele and $160+82 \mathrm{bp}$ for the $\mathrm{T}$ allele variant. The fragments were resolved by electrophoresis in 3.5\% agarose gel after staining with ethidium bromide. In 5 patients the genomic region encompassing the IL-28B rs12979860 C/T polymorphism was sequenced with results confirming those obtained by the RFLP assay.

\section{HBV DNA}

Serum HBV-DNA levels were quantified with the Real Time PCR COBAS AmpliPrep/COBAS TaqMan HBV Test 2.0 (Roche Molecular Systems, NJ, USA). HBsAg, HBeAg, anti-HBs, anti-HBe were detected by the Elecsys instrumental platform (Roche Diagnostics, Italy). 


\section{HDV RNA extraction}

Viral RNA was extracted from $600 \mu \mathrm{l}$ of the sample (serum) using an automated procedure (Qiasymphony, QIAGEN, Hilden, Germany). The manufacturer's protocol was followed, and the purified RNA was eluted in $60 \mu$ l of RNase-free water.

\section{Reverse transcription}

The reverse transcription reaction (RT) was performed using first strand M-MLV reverse transcriptase kit (Invitrogen, Carlsbad, CA, USA) according to the manufacturer's instructions. Briefly, $5 \mu$ l out of the extracted RNA was added to $15 \mu \mathrm{l}$ of RT mixture containing RT buffer, dNTP mix (10 mM each of four deoxynucleoside triphosphate stocks), $50 \mu \mathrm{M}$ random hexamer primer and $75 \mathrm{U}$ of M-MLV reverse transcriptase. The $\mathrm{RT}$ reaction mixture was incubated at $37^{\circ} \mathrm{C}$ for $120 \mathrm{~min}$, and then at $85^{\circ} \mathrm{C}$ for $5 \mathrm{~min}$ to inactivate the enzyme. The resulting $20 \mu \mathrm{l}$ of cDNA was kept at $-20^{\circ} \mathrm{C}$ until use.

\section{Statistical analyses}

Statistical analyses were performed using SPSS, release 20 (IBM Corporation, Chicago, IL, USA). Categorical variables were expressed as frequencies (\%) while continuous variables were presented as mean \pm standard deviation or median with $25^{\text {th }}-75^{\text {th }}$ percentiles inter-quartile range (IQR). Differences between categorical variables were assessed by means of chi-square or Fisher's exact test, while those between continuous variables were evaluated using the Mann-Whitney $U$ test. Multivariate logistic regression analysis with the stepwise forward selection was performed with p-values of less than 0.05 as the criteria for model inclusion. For this model, continuous variables were expressed as dichotomous using median values.

\section{Results}

The total number of patients were 64 ; mean age $31.8 \pm 10.1$ years, median 30.5 (range $13-55$ and interquartile range 23.2-40.0), male 53, median body mass index (BMI) 22.6 (IQR: 20.1-27.7), alanine aminotransferase (ALT) 80 (IQR: 51-118), gamma glutamyl transferase (GGT) 55 (IQR: 30-100). Patients with sustained virologic response were 17 , non-responders, relapsers 11 , and spontaneous clearers post recent superinfection 07 . Cirrhosis of the liver as evident from histology, ultrasound or clinical examination was present in 28 (44\%) and two patient was diabetic. IFN $\lambda 3$, rs12979860 genotype CC was present in $41(64.1 \%)$, CT $21(32.8 \%)$, and TT $02(3.1 \%)$.

There was no difference in the age, BMI, baseline ALT, HBeAg and HBV DNA status among patients with sustained response one year post-treatment and response failures (no response and relapse) to the treatment (Table 1). The median age of response failures was 33.5 (IQR: 25.7-42.7) years compared to 26 (IQR: 21.0-33.5) in responders $(p=0.024)$. They had higher GGT levels $(p=0.030)$ and cirrhosis (0.003). Genotype CC was present in 16/28 patients who showed end of treatment virologic 
Publication: Antiviral Therapy; Type: Original article

DOI: $10.3851 / \mathrm{IMP} 2943$

response (ETR) compared to $22 / 29$ who could not achieve ETR $(p=0.134)$. These figures were $9 / 17$ for sustained responders versus 29/40 for response failures (0.152) (Figure 1). IFN $\lambda 3$, rs12979860 SNP was not associated with any clinical parameter (cirrhosis, ALT and GTT levels). Regression analysis showed that cirrhosis was the independent risk factor for failure to have a sustained response at one year of post treatment follow up $(p=0.001)$. 4/7 patients with spontaneous clearance had genotype CC.

\section{Discussion}

We could not find any beneficial effects of favorable IFN $\lambda 3$ genotype CC on treatment response in hepatitis $D$ in spite of substantial evidence reported with hepatitis $C$. Two recently published papers have discussed the role of IFN $\lambda 3$ polymorphism in hepatitis $D[12,13]$. However, any association of this polymorphism with treatment response still remains in debate. The mechanism by which interferon lambda3 genotypes regulates the antiviral response to the interferon alpha remains unclear. Unlike type I interferons, the target cell populations of interferon-lambda is restricted and mainly include epithelial cells and hepatocytes [14]. Like interferon alpha, interferon lambda upregulates interferon stimulated genes (ISGs) by inducing JAK-STAT Pathway. However, interferon lambda binds to a different receptors than interferon alpha $[15,16]$. Guedj J, et al showed that after initiation of Peg-IFN therapy, a median delay of 9 days was observed with no significant changes in HDV level. Thereafter, HDV declined in a biphasic manner, where a rapid first phase lasting for 25 days was followed by a slower or a plateau second phase. None of the patients with flat second phase in HDV achieved complete viral clearance. The interferon lambda-3 polymorphism (rs12979860) was not associated with kinetic parameters [17].

Genetic analysis of the host may predict which patients are more likely to respond to treatment. IFN $\lambda 3$ genotypes are only one of many factors that might influence the response to Peg-IFN and should be interpreted in the context of other clinical factors. Other factors that play a role in modulating response to the Peg-IFN therapy, may include HDV and HBV genotypes, viral loads, and baseline liver fibrosis. In our country hepatitis $D$ genotype 1 is prevalent [18] and hepatitis $B$ genotype $D$ is present in more than $90 \%$ cases [19]. These genotypes are less responsive to treatment to treatment with interferon. There might be a role of IFN $\lambda 3$ CC genotype in influencing response to Peg-IFN therapy in hepatitis $B$ genotype D patients [4]. However, it is apparent from our study that even having a favorable IFN $\lambda 3$ CC polymorphism was not helpful in our hepatitis D patients (figure 1).

Our patients who cleared the virus in response to treatment were younger, had lower GGT levels and were not having clinical cirrhosis. It has been shown previously that age at the time of diagnosis and the presence of cirrhosis are associated with disease progression in hepatitis $D$ [20]. One way of interpreting our data may be that as the degree of fibrosis in liver progresses with time, the chances of clearing virus become less. 
This study has some limitations of our study. The study included patients who were treated retrospectively. There may be a selection bias as polymorphism was checked in patients who visited the clinic during the study period, not all treated patients as we did not have preserved samples and took samples as they visited us. The number of patients were small. However, sample size is bigger than other two recent studies [12,13], and we included patients treated with Peg-IFN only, not the standard interferon. Though the study relied on the baseline laboratory results done in the past, the tests were done in a single center. Baseline quantitative PCR and HBsAg levels, and early virological response at week 12 were not available in all patients so these variables could not be analyzed.

Spontaneous clearance of both viruses is seen in patients with HBV and HDV confection, but seven patients with spontaneous clearance in our study were HBsAg positive even before HDV exposure suggesting that these patients most likely had superinfection and then cleared the virus as documented from their records. The number is small to draw any conclusion and the natural comparator group for spontaneous clearers in a larger study would be all those patients who did not clear the virus spontaneously. The long-term follow-up studies indicate that several patients defined as responders after a follow-up of six months relapse in the long run [21]. We defined responders who had undetectable HDV RNA one year after stopping the treatment. There is a possibility that some of the responders would have become relapsers if had followed up for a longer duration. The study cohort does not include any patient who had cleared HBsAg as well. The lack of effect of rs12979860 SNP would not rule out other the role of other SNPs which need to be addressed in future studies.

In conclusion, IFN $\lambda 3$ rs12979860 SNPs in patients infected with HDV does not have any significant influence on the long term virologic clearance. The degree of fibrosis may influence the response to the Peg-IFN therapy.

\section{Disclosure statement}

There are no conflicts of interest to declare relevant to this article.

\section{References}

1. Ge D, Fellay J, Thompson AJ, et al. Genetic variation in IL28B predicts hepatitis C treatmentinduced viral clearance. Nature 2009; 461:399-401.

2. Thompson AJ, Muir AJ, Sulkowski MS, et al. Interleukin-28B polymorphism improves viral kinetics and is the strongest pre-treatment predictor of sustained virologic response in hepatitis $C$ virus-1 paitents. Gastroenterology 2010; 139:120-129.

3. Galmozzi E, Viganò M, Lampertico P. Systematic review with meta-analysis: do interferon lambda 3 polymorphisms predict the outcome of interferon-therapy in hepatitis B infection? Aliment Pharmacol Ther 2014; 39:569-578.

4. Boglione L, Cusato J, Allegra S, et al. Role of IL28-B polymorphisms in the treatment of chronic hepatitis B HBeAg-negative patients with peginterferon. Antiviral Res 2014; 102:35-43.

5. Abbas Z, Jafri W, Raza S, Hepatitis D. Scenario in the Asia-Pacific region. World J Gastroenterol 2010; 16:554-562. 
6. Seetlani NK, Abbas Z, Raza S, Yakoob J, Jafris W. Prevalence of hepatitis D in HBsAg positive patients visiting liver clinics. J Pak Med Assoc 2009; 59:434-437.

7. Mumtaz K, Hamid SS, Adil S, et al. Epidemiology and clinical pattern of hepatitis delta virus infection in Pakistan. J Gastroenterol Hepatol 2005; 20:1503-1507.

8. Abbas Z, Khan MA, Salih M, Jafri W. Interferon alpha for chronic hepatitis D. Cochrane Database Syst Rev 2011; (12):CD006002.

9. Abbas Z, Memon MS, Mithani H, Jafri W, Hamid S. Treatment of chronic hepatitis D patients with pegylated interferon: a real world experience. Antivir Ther 2014; 19:463-468.

10. Wedemeyer H, Yurdaydìn C, Dalekos GN, et al. Peginterferon plus adefovir versus either drug alone for hepatitis delta. N Engl J Med 2011; 364:322-331.

11. Fabris C, Falleti E, Cussigh A, et al. IL-28B rs12979860 C/T allele distribution in patients with liver cirrhosis: role in the course of chronic viral hepatitis and the development of HCC. J Hepatol 2011; 54:716-722.

12. Yilmaz E, Baran B, Soyer OM, et al. Effects of polymorphisms in interferon $\lambda 3$ (interleukin 28B) on sustained virologic response to therapy in patients with chronic hepatitis $D$ virus infection. Clin Gastroenterol Hepatol 2014; 12:1753-1758.

13. Visco-Comandini U, Lapa D, Taibi C, Angeletti C, Capobianchi MR, Garbuglia AR. No impact of interleukin-28B polymorphisms on spontaneous or drug-induced hepatitis delta virus clearance. Dig Liver Dis 2014; 46:348-352.

14. Witte K, Witte E, Sabat R, Wolk K. IL-28A, IL-28B, and IL-29: promising cytokines with type I interferon-like properties. Cytokine Growth Factor Rev 2010; 21:237-251.

15. Kotenko SV, Gallagher G, Baurin VV, et al. IFN-lambdas mediate antiviral protection through a distinct class II cytokine receptor complex. Nat Immunol 2003; 4:69-77.

16. Sheppard P, Kindsvogel W, Xu W, et al. IL-28, IL-29 and their class II cytokine receptor IL-28R. Nat Immunol 2003; 4:63-68.

17. Guedj J, Rotman Y, Cotler SJ, et al. Understanding early serum hepatitis D virus and hepatitis B surface antigen kinetics during pegylated interferon-alpha therapy via mathematical modeling. Hepatology 2014; 60:1902-1910.

18. Moatter T, Abbas Z, Shabir S, Jafri W. Clinical presentation and genotype of hepatitis delta in Karachi. World J Gastroenterol 2007; 13:2604-2607.

19. Abbas Z, Muzaffar R, Siddiqui A, Naqvi SA, Rizvi SA. Genetic variability in the precore and core promoter regions of hepatitis B virus strains in Karachi. BMC Gastroenterol 2006; 6:20.

20. Buti M, Homs M, Rodriguez-Frias F, et al. Clinical outcome of acute and chronichepatitis delta over time: a long-term follow-up study. J Viral Hepat 2011; 18:434-442.

21. Heidrich B, Yurdaydın C, Kabaçam G, et al. Late HDV RNA relapse after peginterferon alphabased therapy of chronic hepatitis delta. Hepatology 2014; 60:87-97. 
Publication: Antiviral Therapy; Type: Original article

DOI: 10.3851/IMP2943

Figure 1. IFN $\lambda 3$ rs $12979860, C C$ or non-CC genotypes, and response to pegylated interferon in patients with hepatitis D.

ETR: end of treatment virological response; VR-1: virological response persisting one year post-treatment.

Table 1: Characteristics of patients who received pegylated interferon therapy

\begin{tabular}{|c|c|c|c|}
\hline & $\begin{array}{l}\text { Responders } \\
\mathrm{N}=17\end{array}$ & $\begin{array}{l}\text { Non-responders and } \\
\text { relapsers } \\
\mathrm{n}=40\end{array}$ & $P$ value \\
\hline $\begin{array}{l}\text { Gender } \\
\text { male } \\
\text { female }\end{array}$ & $\begin{array}{l}14(82 \%) \\
03\end{array}$ & $\begin{array}{l}34(85 \%) \\
06\end{array}$ & 1.00 \\
\hline $\begin{array}{l}\text { Age } \\
\text { mean } \pm S . D . \\
\text { Median (IQR) }\end{array}$ & $\begin{array}{l}27.2 \pm 7.6 \\
26(21.0-33.5)\end{array}$ & $\begin{array}{l}34.0 \pm 10.6 \\
33.5(25.2-42.7)\end{array}$ & $0.024^{\star}$ \\
\hline $\begin{array}{l}\text { Body mass index }\left(\mathrm{kg} / \mathrm{m}^{2}\right) \\
\text { mean } \pm S . \mathrm{D} \\
\text { median }(\mathrm{IQR})\end{array}$ & $\begin{array}{l}24.0 \pm 4.7 \\
23.2(20.1-28.3)\end{array}$ & $\begin{array}{l}23.7 \pm 5.6 \\
22.5(20.0-27.0)\end{array}$ & 0.711 \\
\hline Cirrhosis & 2 & 22 & $0.003^{*}$ \\
\hline $\begin{array}{l}\text { Alanine aminotransferase (IU/L) } \\
\text { mean } \pm S . D \text {. } \\
\text { median (IQR) }\end{array}$ & $\begin{array}{l}147 \pm 180 \\
87(56.5-137.5)\end{array}$ & $\begin{array}{l}103 \pm 78 \\
94(49-118)\end{array}$ & 0.545 \\
\hline $\begin{array}{l}\text { Gamma glutamyl transferase (IU/L) } \\
\text { mean } \pm \text { S.D. } \\
\text { median (IQR) }\end{array}$ & $\begin{array}{l}51 \pm 39 \\
36(30.0-64.5)\end{array}$ & $\begin{array}{l}103 \pm 97 \\
80.5(31.7-132.2)\end{array}$ & $0.030^{*}$ \\
\hline $\mathrm{HBe} A g$ reactive & $4(24 \%)$ & $16(40 \%)$ & 0.364 \\
\hline HBV DNA detected & $3(18 \%)$ & $14(35 \%)$ & 0.224 \\
\hline $\begin{array}{l}\text { Interferon } \lambda 3 \text { type } \\
\text { CC } \\
\text { non-CC }\end{array}$ & $\begin{array}{l}9(53 \%) \\
8\end{array}$ & $\begin{array}{l}29(73 \%) \\
11\end{array}$ & 0.152 \\
\hline
\end{tabular}

$P$ values by Fisher exact test or Man-Whitney $U$ test. *statistically significant $p$ values S.D.: standard deviation; IQR: interquartile range 


\section{rs12979860 polymorphism}

aCC non-CC

\begin{tabular}{r|r}
$100 \%$ & \\
$90 \%$ & \\
$80 \%$ & 12 \\
$70 \%$ & \\
$60 \%$ & \\
$50 \%$ & \\
$40 \%$ & \\
$30 \%$ & 16 \\
$20 \%$ & \\
$10 \%$ & \\
$0 \%$ & \\
& ETR
\end{tabular}
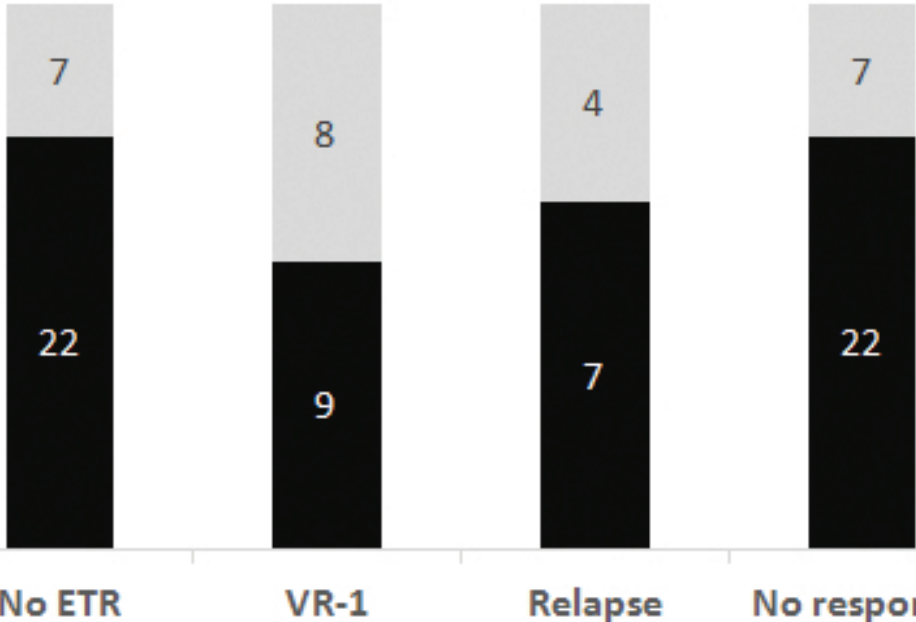

Relapse

No response 